\title{
Association between circulating CD34- positive cells and serum alkaline phosphatase in relation to body mass index for elderly Japanese men
}

Yuji Shimizu ${ }^{1 *}$, Shimpei Sato ${ }^{1}$, Jun Koyamatsu², Hirotomo Yamanashi², Mako Nagayoshi', Koichiro Kadota', Kazuto Tsuruda ${ }^{3}$, Naomi Hayashida ${ }^{4}$, Norio Abiru ${ }^{5}$, Hironori Yamasaki ${ }^{6}$, Noboru Takamura ${ }^{7}$ and Takahiro Maeda ${ }^{1,2}$

\begin{abstract}
Background: Recent studies have confirmed an association between bone metabolism and vascular homeostasis. However, no study has examined the relationship between serum alkaline phosphatase (ALP) (a marker of bone metabolism) and circulating immature cell such as CD34-positive cells (a marker of vascular homeostasis).

Methods: We conducted a cross-sectional study of this association in 272 elderly Japanese men (60-79 years). Because low body mass index (BMI) status is a known characteristic of Japanese with a high incidence rate of stroke, we used a stratified analysis based on BMI.

Results: Multivariable linear regression analysis adjusted for confounding factors showed a significant correlation between serum ALP and the number of circulating CD34-positive cells, especially for participants with low BMI $\left(<23 \mathrm{~kg} / \mathrm{m}^{2}\right)$. The parameter estimates $(\beta)$ and $95 \%$ confidence intervals $(\mathrm{Cl})$ for one standard deviation increments in serum ALP levels $(62 \mathrm{IU} / \mathrm{L})$ for the circulating CD34-positive cell count were $\beta=0.25(0.04,0.45)$ for total subjects, $\beta=0.45(0.16,0.75)$ for participants with low BMl $\left(<23 \mathrm{~kg} / \mathrm{m}^{2}\right)$, and $\beta=0.04(-0.25,0.34)$ for participants with high BMI $\left(\geq 23 \mathrm{~kg} / \mathrm{m}^{2}\right)$.

Conclusion: Serum ALP correlates positively with circulating CD34-positive cells among a general population of elderly Japanese men, especially those with low BMI $\left(<23 \mathrm{~kg} / \mathrm{m}^{2}\right)$. These findings suggest that serum ALP levels may constitute an efficient tool for estimating the risk of insufficient vascular homeostasis, especially for participants with relatively few classical cardiovascular risk factors.
\end{abstract}

\section{Introduction}

A previous study reported identifying a positive association between elevated serum alkaline phosphatase (ALP) and atherosclerosis [1]. Other prospective studies have identified an association between high serum ALP levels and mortality from all causes or cardiovascular disease for subjects with previous myocardial infarction [2] and previous stroke [3], in a clinic population [4], as well as a general population [2]. However, in a retrospective study of ours as part of the Circulatory Risk in Communities Study (CIRCS), we reported that not only

\footnotetext{
* Correspondence: simizicyuu@yahoo.co.jp

${ }^{1}$ Department of Community Medicine, Nagasaki University Graduate School of Biomedical Sciences, Nagasaki, Japan

Full list of author information is available at the end of the article
}

high but also low serum ALP levels may be a predictor of risk of stroke for Japanese [5]. Other recent studies reported detecting associations between bone metabolism and vascular homeostasis [6-13] in view of the fact that hematopoietic stem cells (immature cell such as CD34-positive cell) derived from the bone marrow play a major role in vascular homeostasis [7-9]. Because osteoblasts, whose activity can be evaluated in terms of bone-type ALP expression [14, 15], regulate the production of hematopoietic stem cells in the bone marrow [10-12], serum ALP levels may be related to vascular homeostatic activity. Another study reported that a reduction in the number of endothelial progenitor cells (CD34-positive cells) is associated with an increase in 
the number of infarctions in patients with ischemic stroke [16].

However, no study has examined whether the number of circulating CD34-positive cells is associated with serum ALP levels. In this connection, the prevalence of obesity in adults defined by a body mass index (BMI) of $\geq 30 \mathrm{~kg} / \mathrm{m}^{2}$ was only $3.6 \%$ in Japan whereas it was $35.3 \%$ in the USA in 2012 [17]. Nevertheless, the incidence of stroke and stroke mortality is higher in East Asian countries than in Western countries [18]. Since only a study of a Japanese general population has identified a risk of stroke in association with lower serum ALP level [5], the association between serum ALP level and the number of circulating CD34-positive cells may be strongly influenced by BMI status.

To investigate the validity of this hypothesis, we conducted a cross-sectional study of elderly Japanese men aged $60-79$ years.

\section{Materials and methods Subjects}

Written consent forms were available in Japanese to ensure comprehensive understanding of the study objectives, and informed consent was signed by all participants. Since postmenopausal changes such as osteopenia, osteoporosis [19], and dyslipidemia are known to have a major impact on serum ALP levels, women were not considered suitable subjects for an analysis of the association between serum ALP and circulating CD34-positive cells. The survey population comprised 409 60-79-year-old men who underwent a general medical check-up as recommended by the Japanese government. They were residents of rural communities in the Goto Islands in western Japan and participated in this study in 2013 and 2014.

Persons with missing data $(n=132)$ were excluded. To avoid the effect of bone disorders such as osteoporosis, bone fracture, and bone tumor, we also excluded persons with a high serum ALP level $(>400 \mathrm{IU} / \mathrm{L})(n=5)$. The remaining 272 men with a mean age of 66.6 years (standard deviation (SD) \pm 4.4 ; range $60-79$ ), none of whom were taking medication for anemia, were enrolled in this study, which was approved by the Ethics Committee for Human Use of Nagasaki University (project registration number 0501120073).

\section{Data collection and laboratory measurements}

Body weight and height were measured with an automatic body composition analyzer (BF-220; Tanita, Tokyo, Japan) when blood samples were obtained, and BMI $\left(\mathrm{kg} / \mathrm{m}^{2}\right)$ was calculated. Systolic blood pressure and diastolic blood pressure were recorded at rest.

Fasting blood samples were collected in a heparin sodium tube and a siliconized tube. Fresh samples (within
$24 \mathrm{~h}$ from obtained) from the former were used for determining the number of CD34-positive cells. BD (Beckton Dickinson Biosciences) Trucount ${ }^{\mathrm{Tx}}$ technology for an accurate and reproducible single platform assay with International Society of Hematotherapy and Graft Engineering (ISHAGE) guidelines [20, 21] which was supported by an automated software on the BD FACSCant ${ }^{\text {tw }}$ II system was used to measuring circulating CD34positive cells. Serum samples were separated for the measurement of concentrations of alkaline phosphatase (ALP), aspartate aminotransferase (AST), serum alanine aminotransferase (ALT), and $\gamma$-glutamyltranspeptidase $(\gamma$-GTP) with the Japanese Society of Clinical Chemistry (JSCC) standardization method.

Triglyceride (TG) and creatinine were measured with the enzyme method. HDL-cholesterol (HDL), calcium $(\mathrm{Ca})$, and phosphorus $(\mathrm{P})$ were measured by direct method, Arsenazo III method, and molybdate direct method, respectively. Hemoglobin A1c $\left(\mathrm{HbA}_{1 \mathrm{c}}\right)$ was measured with the latex coagulation method. The glomerular filtration rate (GFR) was estimated by means of an established method with three variations recently proposed by a working group of the Japanese Chronic Kidney Disease initiative [22]. According to this adapted version, GFR $\left(\mathrm{mL} / \mathrm{min} / 1.73 \mathrm{~m}^{2}\right)=194 \times($ serum creatinine (enzyme method) $)^{-1.094} \times(\text { age })^{-0.287}$.

\section{Statistical analysis}

Characteristics of the study participants were expressed in terms of BMI status.

Simple correlation analyses of serum ALP and other variables affecting BMI status, as well as of the numbers of CD34-positive cells and other variables, were performed. Multiple linear regression analysis was performed to determine the correlations between the number of circulating CD34-positive cells and one SD increment in ALP (62 IU/L). Because ALP is expressed differently in various tissues, with notably high concentrations in the liver, bone, and kidneys [14], we designed the analyses to allow for adjustments for classical cardiovascular risks factors and factors associated with the liver, as well as factors that might be directly involved in bone metabolism. The latter factors comprised age, systolic blood pressure $(\mathrm{mmHg})$, diastolic blood pressure $(\mathrm{mmHg})$, body mass index, smoking status (never smoker, former smoker, current smoker), alcohol consumption (never drinker, former drinker, current drinker $[<23,23-45,46-68, \geq 69$ g/week]), HbA1c (\%), HDL (mg/dL), TG (mg/dL), AST (IU/L), ALT (IU/L), $\gamma$-GTP (IU/L), Ca $(\mathrm{mg} / \mathrm{dL}), \mathrm{P}(\mathrm{mg} / \mathrm{dL})$, and GFR $(\mathrm{mL} / \mathrm{min} /$ $\left.1.72 \mathrm{~m}^{2}\right)$.

All statistical analyses were performed with the SAS system for Windows (version 9.3; SAS Inc., Cary, NC). 
Probability values less than 0.05 were considered indicative of statistical significance.

\section{Results}

Table 1 shows the characteristics of the study population. Compared to participants with low BMI (defined as $<23 \mathrm{~kg} / \mathrm{m}^{2}$ ), participants with high BMI (defined as $\geq 23 \mathrm{~kg} / \mathrm{m}^{2}$ ) show significantly higher systolic blood pressure, diastolic blood pressure, TG, ALT, $\gamma$-GTP, HbA1c, and serum creatinine while significantly lower HDL and GFR.

Simple correlation analysis was used to determine associations of serum ALP with other variables affecting BMI status (Table 2). For total subjects, serum ALP correlated positively with age, TG, and AST and negatively with HDL and alcohol consumption. Stratification of those correlations by BMI status disclosed that ALP correlated with TG for both participants with low BMI and high BMI. We also found that ALP correlated positively with AST and $\gamma$-GTP and negatively with alcohol consumption and HDL for high BMI and positively with age for low BMI.

Simple correlation analyses of the number of circulating CD34-positive cells and other variables are shown in Table 3 . The cells showed a significantly positive correlation with serum ALP for total $(r=0.14, p=0.020)$ and low BMI $(r=0.29, p=0.001)$ but not for high BMI $(r=0.04, p=$ 0.637). We also determined the correlation between number of circulating CD34-positive cells and a one SD increment in serum ALP (Fig. 1).

As shown in Table 4, multiple linear regression analysis adjustment for confounding factors showed that the number of circulating CD34-positive cells correlated positively with a one SD increment in serum ALP for total $(\beta=0.25, p=0.019)$ and low BMI $(\beta=0.45, p=$ $0.003)$ but not for high BMI $(\beta=0.04, p=0.772)$.

\section{Discussion}

The major finding of this study of elderly Japanese men was that serum ALP significantly and positively correlates with circulating CD34-positive cells, especially for participants with low BMI $\left(<23 \mathrm{~kg} / \mathrm{m}^{2}\right)$. This suggests that serum ALP levels may constitute an efficient tool for estimating the risk of insufficient vascular homeostasis, especially for participants with relatively few classical cardiovascular risk factors.

The mechanism most likely to be responsible for the association between serum ALP and circulating CD34positive cell is impaired vascular homeostasis since hematopoietic stem cells derived from the bone marrow play a major role in vascular homeostasis [7-9]. Moreover, because osteoblasts (whose activity can be assessed in terms of bone-type ALP expression [14, 15]) regulate the production of hematopoietic stem cells in the bone marrow [10-12], serum ALP level may correlate with vascular homeostatic activity, and a prospective study

Table 1 Age-adjusted characteristics of study population by BMI status

\begin{tabular}{|c|c|c|c|}
\hline & $\mathrm{BMI}<23 \mathrm{~kg} / \mathrm{m}^{2}$ & $\mathrm{BMI} \geq 23 \mathrm{~kg} / \mathrm{m}^{2}$ & $p$ value \\
\hline No. of participants & 122 & 150 & \\
\hline Age, years & $66.5 \pm 4.4$ & $66.7 \pm 4.4$ & \\
\hline Circulating CD34-positive cells, cells/ $\mu \mathrm{L}$ & 1.33 & 1.55 & 0.231 \\
\hline Serum alkaline phosphatase (ALP), UI/L & 239 & 225 & 0.065 \\
\hline Systolic blood pressure, $\mathrm{mmHg}$ & 134 & 139 & 0.016 \\
\hline Diastolic blood pressure, $\mathrm{mmHg}$ & 81 & 87 & $<0.001$ \\
\hline Body mass index (BMI), $\mathrm{kg} / \mathrm{m}^{2}$ & 20.9 & 25.7 & $<0.001$ \\
\hline Current drinker, \% & 76.4 & 84.5 & 0.088 \\
\hline Current smoker, \% & 28.4 & 20.3 & 0.111 \\
\hline Serum HDL-cholesterol (HDL), mg/dL & 61 & 54 & $<0.001$ \\
\hline Serum triglycerides (TG), mg/dL & 104 & 127 & 0.046 \\
\hline Hemoglobin A1c (HbA1c), \% & 5.6 & 5.8 & 0.027 \\
\hline Serum aspartate aminotransferase (AST), IU/L & 24 & 26 & 0.105 \\
\hline Serum alanine aminotransferase (ALT), IU/L & 20 & 26 & $<0.001$ \\
\hline Serum $\gamma$-glutamyltranspeptidase ( $\gamma-G T P), ~ I U / L$ & 36 & 53 & 0.007 \\
\hline Serum calcium (Ca), mg/dL & 9.3 & 9.3 & 0.208 \\
\hline Serum phosphorus $(P), \mathrm{mg} / \mathrm{dL}$ & 3.3 & 3.3 & 0.455 \\
\hline Serum creatinine, mg/dL & 0.82 & 0.86 & 0.016 \\
\hline Glomerular filtration rate (GFR), mL/min/1.73 $\mathrm{m}^{2}$ & 75.1 & 71.2 & 0.023 \\
\hline
\end{tabular}

Age: mean \pm standard deviation 
Table 2 Simple correlation analysis of ALP and other variables

\begin{tabular}{|c|c|c|c|c|c|c|}
\hline & Total s & & $\mathrm{BMl}<2$ & & $\mathrm{BMI} \geq$ & \\
\hline & $r$ & $p$ & $r$ & $p$ & $r$ & $p$ \\
\hline No. of participants & 272 & & 122 & & 150 & \\
\hline Age & 0.16 & 0.010 & 0.22 & 0.017 & 0.11 & 0.165 \\
\hline Systolic blood pressure & 0.11 & 0.072 & 0.10 & 0.287 & 0.16 & 0.056 \\
\hline Diastolic blood pressure & 0.06 & 0.364 & 0.08 & 0.383 & 0.09 & 0.255 \\
\hline Body mass index (BMI) & -0.08 & 0.190 & -0.14 & 0.115 & 0.12 & 0.156 \\
\hline Alcohol consumption & -0.20 & $<0.001$ & -0.13 & 0.149 & -0.24 & 0.003 \\
\hline Smoking status & 0.05 & 0.423 & 0.05 & 0.567 & 0.03 & 0.698 \\
\hline Serum HDL-cholesterol (HDL) & -0.19 & 0.002 & -0.13 & 0.140 & -0.30 & $<0.001$ \\
\hline Serum triglycerides (TG) & 0.29 & $<0.001$ & 0.24 & 0.008 & 0.36 & $<0.001$ \\
\hline Hemoglobin A1c (HbA1c) & 0.04 & 0.536 & 0.04 & 0.635 & 0.06 & 0.454 \\
\hline Serum aspartate aminotransferase (AST) & 0.13 & 0.033 & 0.05 & 0.583 & 0.20 & 0.013 \\
\hline Serum alanine aminotransferase (ALT) & 0.08 & 0.205 & 0.04 & 0.670 & 0.15 & 0.061 \\
\hline Serum $\gamma$-glutamyltranspeptidase ( $\gamma$-GTP) & 0.09 & 0.119 & 0.01 & 0.879 & 0.16 & 0.046 \\
\hline Serum creatinine & -0.07 & 0.279 & -0.12 & 0.190 & 0.002 & 0.980 \\
\hline Glomerular filtration rate (GFR) & 0.07 & 0.263 & 0.09 & 0.306 & -0.02 & 0.773 \\
\hline Serum calcium (Ca) & -0.11 & 0.078 & -0.12 & 0.175 & -0.08 & 0.325 \\
\hline Serum phosphorus $(P)$ & -0.08 & 0.191 & -0.10 & 0.266 & -0.07 & 0.385 \\
\hline
\end{tabular}

Alcohol consumption [never drinker, former drinker, current drinker $(<23,23-45,46-68, \geq 69 \mathrm{~g} /$ week)] and smoking status (never smoker, former smoker, current smoker)

Table 3 Simple correlation analysis of number of circulating CD34-positive cells and other variables

\begin{tabular}{|c|c|c|c|c|c|c|}
\hline & \multicolumn{2}{|c|}{ Total subjects } & \multicolumn{2}{|c|}{$\mathrm{BMI}<23 \mathrm{~kg} / \mathrm{m}^{2}$} & \multicolumn{2}{|c|}{$\mathrm{BMI} \geq 23 \mathrm{~kg} / \mathrm{m}^{2}$} \\
\hline & $r$ & $p$ & $r$ & $p$ & $r$ & $p$ \\
\hline No. of participants & 272 & & 122 & & 150 & \\
\hline Age & -0.04 & 0.460 & 0.09 & 0.349 & -0.15 & 0.072 \\
\hline Systolic blood pressure & -0.04 & 0.503 & -0.02 & 0.856 & -0.08 & 0.309 \\
\hline Diastolic blood pressure & -0.01 & 0.894 & 0.06 & 0.520 & -0.09 & 0.250 \\
\hline Body mass index (BMI) & 0.03 & 0.642 & 0.04 & 0.666 & -0.10 & 0.202 \\
\hline Alcohol consumption & -0.03 & 0.623 & -0.04 & 0.652 & -0.04 & 0.646 \\
\hline Smoking status & -0.03 & 0.611 & -0.002 & 0.983 & -0.05 & 0.576 \\
\hline Serum HDL-cholesterol (HDL) & -0.03 & 0.633 & 0.04 & 0.689 & -0.06 & 0.466 \\
\hline Serum triglycerides (TG) & 0.10 & 0.073 & 0.08 & 0.353 & 0.11 & 0.171 \\
\hline Hemoglobin A1c (HbA1c) & 0.10 & 0.118 & -0.02 & 0.829 & 0.18 & 0.028 \\
\hline Serum aspartate aminotransferase (AST) & -0.05 & 0.490 & -0.07 & 0.459 & -0.04 & 0.631 \\
\hline Serum alanine aminotransferase (ALT) & 0.05 & 0.419 & -0.05 & 0.579 & 0.07 & 0.364 \\
\hline Serum $\gamma$-glutamyltranspeptidase ( $\gamma$-GTP) & 0.01 & 0.863 & 0.04 & 0.635 & -0.02 & 0.837 \\
\hline Glomerular filtration rate (GFR) & -0.03 & 0.616 & -0.04 & 0.696 & -0.01 & 0.902 \\
\hline Serum calcium (Ca) & 0.002 & 0.978 & -0.01 & 0.932 & -0.001 & 0.989 \\
\hline Serum phosphorus (P) & -0.04 & 0.563 & -0.10 & 0.240 & 0.02 & 0.790 \\
\hline Serum alkaline phosphatase (ALP) & 0.14 & 0.020 & 0.29 & 0.001 & 0.04 & 0.637 \\
\hline
\end{tabular}

Alcohol consumption [never drinker, former drinker, current drinker ( $<23,23-45,46-68, \geq 69 \mathrm{~g} /$ week)] and smoking status (never smoker, former smoker, current smoker) 


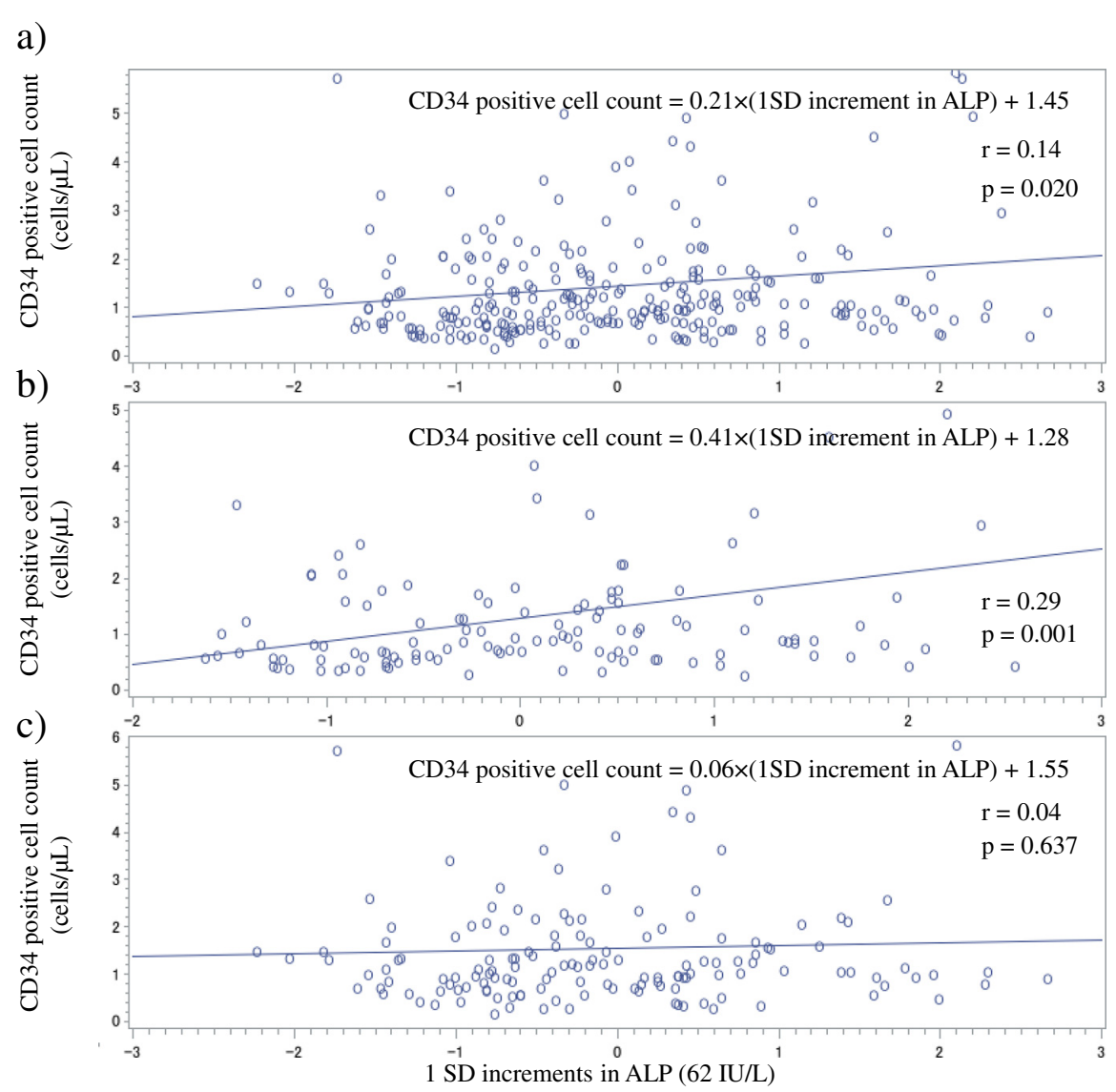

Fig. 1 Relationship between circulating CD34-positive cells and one SD increment in serum ALP in a total subjects, b those with low BMI $\left(<23 \mathrm{~kg} / \mathrm{m}^{2}\right)$, and $\mathbf{c}$ those with high BMI $\left(\geq 23 \mathrm{~kg} / \mathrm{m}^{2}\right)$

reported a strong association between a reduced number of endothelial progenitor cells (CD34-positive and KDRpositive cell) and risk of cardiovascular disease [23]. Yet another study found an association of a reduction in the number of endothelial progenitor cells (CD34-positive cells) with an increase in the number of infarctions $>5 \mathrm{~mm}$ in diameter, but no such association with atherosclerosis in carotid arteries of patients with ischemic stroke [16]. Endothelial progenitor cells contribute to vascular repair [24, 25], and a reduction in the number of these cells may thus increase the risk of stroke. Results of another retrospective CIRCS study of ours indicated that not only higher but also lower serum ALP levels may be a predictor of the risk of stroke among Japanese [5]. These findings seem to be, at least in part, compatible with those of our present study.

Since hematopoietic stem cells have also been reported to participate in the pathogenesis of atherosclerosis [13], an increase in serum ALP may be associated with the deterioration of arterial stiffness. A previous study reported that, independent of other traditional cardiovascular risk factors, elevated serum ALP is associated with atherosclerosis evaluated by means of ankle-brachial blood pressure index [1]. However, in our subsequent analysis $(n=191)$, we could not find any association between serum ALP and arterial stiffness evaluated by cardio-ankle vascular index (CAVI) $(r=-0.02 ; P=0.874)$. Since our study population consists of elderly subjects and side population hematopoietic bone marrow stem cells diminish as individuals age [26, 27], so that even vascular injury can activate bone marrow metabolism, the bone marrow could not be activated as it would be in younger participants while the atherosclerotic lesion might have originated in their younger years. Furthermore, extensive reduction in bone marrow activity also may have a confounding effect on the aforementioned associations. The significant correlation between serum ALP and circulating CD34-positive cells observed in our study was therefore restricted to low BMI. In addition, participants with high BMI possessed many more classical cardiovascular risk factors such as metabolic syndrome than did those with lower BMI $\left(<23 \mathrm{~kg} / \mathrm{m}^{2}\right)$. In this connection, the World Health Organization (WHO) has identified BMI $\geq 23 \mathrm{~kg} / \mathrm{m}^{2}$, which corresponds to the median BMI in our study, as an indicator for enhanced risk of disease for Asian populations [28]. Another 
Table 4 Multiple linear regression analysis of circulating CD34-positive cells with relevant factors adjusted for confounding factors

\begin{tabular}{|c|c|c|c|c|c|c|c|c|c|}
\hline & Total su & ubjects & & $\mathrm{BMI}<2$ & $3 \mathrm{~kg} / \mathrm{m}^{2}$ & & $\mathrm{BMI} \geq 2$ & $3 \mathrm{~kg} / \mathrm{m}^{2}$ & \\
\hline & $\bar{\beta}$ & $95 \% \mathrm{Cl}$ & $p$ & $\bar{\beta}$ & $95 \% \mathrm{Cl}$ & $p$ & $\bar{\beta}$ & $95 \% \mathrm{Cl}$ & $p$ \\
\hline No. of participants & 272 & & & 122 & & & 150 & & \\
\hline Age & -0.02 & $(-0.06,0.03)$ & 0.467 & 0.02 & $(-0.04,0.09)$ & 0.485 & -0.07 & $\begin{array}{l}(-014 \\
-0.004)\end{array}$ & 0.038 \\
\hline Systolic blood pressure & -0.01 & $(-0.02,0.01)$ & 0.462 & -0.02 & $(-0.04,0.01)$ & 0.175 & 0.005 & $(-0.02,0.03)$ & 0.671 \\
\hline Diastolic blood pressure & -0.002 & $(-0.03,0.02)$ & 0.852 & 0.02 & $(-0.02,0.06)$ & 0.360 & -0.02 & $(-0.06,0.01)$ & 0.152 \\
\hline Body mass index (BMI) & 0.01 & $(-0.06,0.09)$ & 0.749 & 0.10 & $(-0.09,0.29)$ & 0.291 & -0.11 & $(-0.25,0.03)$ & 0.134 \\
\hline Alcohol consumption & 0.02 & $(-0.09,0.13)$ & 0.682 & -0.02 & $(-0.19,0.14)$ & 0.770 & -0.01 & $(-0.16,0.14)$ & 0.906 \\
\hline Smoking status & -0.13 & $(-0.42,0.16)$ & 0.390 & 0.04 & $(-0.41,0.48)$ & 0.874 & -0.31 & $(-0.72,0.09)$ & 0.129 \\
\hline Serum HDL-cholesterol (HDL) & 0.01 & $(-0.01,0.02)$ & 0.400 & 0.02 & $(-0.005,0.04)$ & 0.138 & -0.003 & $(-0.03,0.02)$ & 0.800 \\
\hline Serum triglycerides (TG) & 0.001 & $\begin{array}{l}(-0.001 \\
0.003)\end{array}$ & 0.333 & 0.001 & $\begin{array}{l}(-0.003 \\
0.005)\end{array}$ & 0.736 & 0.002 & $(-0.001,0.01)$ & 0.178 \\
\hline Hemoglobin A1c (HbA1c) & 0.14 & $(-0.16,0.44)$ & 0.367 & -0.09 & $(-0.55,0.37)$ & 0.704 & 0.44 & $(-0.01,0.89)$ & 0.056 \\
\hline Serum aspartate aminotransferase (AST) & -0.03 & $(-0.06,0.01)$ & 0.104 & -0.03 & $(-0.09,0.02)$ & 0.241 & -0.03 & $(-0.07,0.02)$ & 0.252 \\
\hline Serum alanine aminotransferase (ALT) & 0.02 & $(-0.01,0.04)$ & 0.250 & 0.01 & $(-0.04,0.06)$ & 0.767 & 0.01 & $(-0.02,0.05)$ & 0.387 \\
\hline Serum $\gamma$-glutamyltranspeptidase ( $\gamma$-GTP) & 0.001 & $\begin{array}{l}(-0.004 \\
0.005)\end{array}$ & 0.821 & 0.004 & $(-0.01,0.02)$ & 0.468 & 0.001 & $(-0.004,0.01)$ & 0.701 \\
\hline Glomerular filtration rate (GFR) & -0.004 & $(-0.02,0.01)$ & 0.571 & -0.004 & $(-0.02,0.02)$ & 0.703 & -0.003 & $(-0.02,0.02)$ & 0.775 \\
\hline Serum calcium (Ca) & 0.01 & $(-0.56,0.58)$ & 0.970 & 0.06 & $(-0.82,0.94)$ & 0.889 & -0.11 & $(-0.88,0.66)$ & 0.776 \\
\hline Serum phosphorus (P) & -0.13 & $(-0.56,0.31)$ & 0.565 & -0.06 & $(-0.76,0.63)$ & 0.854 & 0.05 & $(-0.56,0.65)$ & 0.88 \\
\hline $\begin{array}{l}\text { One SD increment in serum alkaline phosphatase } \\
\text { (ALP) }\end{array}$ & 0.25 & $(0.04,0.45)$ & 0.019 & 0.45 & $(0.16,0.75)$ & 0.003 & 0.04 & $(-0.25,0.34)$ & 0.772 \\
\hline
\end{tabular}

Alcohol consumption [never drinker, former drinker, current drinker $(<23,23-45,46-68, \geq 69 \mathrm{~g} /$ week)] and smoking status (never smoker, former smoker, current smoker)

possible mechanism that might explain why a significant correlation between serum ALP and the number of circulating CD34-positive cells is limited to low BMI $\left(<23 \mathrm{~kg} / \mathrm{m}^{2}\right)$ is the fact that the factors that determine the serum ALP levels are different. Serum ALP is classified in terms of isoenzymes, that is, liver-type, bonetype, and intestinal-type [29]. For the subjects with high BMI in our study, serum ALP levels are much more likely to be influenced by factors associated with liver condition such as alcohol consumption, HDL, AST, and $\gamma$-GTP than for the subjects with low BMI. Furthermore, the simple correlation analyses showed significant correlations between the number of circulating CD34-positive cells and HbA1c for high BMI but not for low BMI $\left(\geq 23 \mathrm{~kg} / \mathrm{m}^{2}\right)$. Since HbA1c levels were significantly higher for subjects with high BMI than for those with low BMI, HbA1c could be an important stimulating factor for circulating CD34-positive cell production in subjects with high BMI but not with low BMI.

Our findings should be interpreted with some caution. First, because the ALP isoenzyme was not measured [29], we could not assess which type of ALP correlated with circulating CD34-positive cells. However, in the present study, we detected a significant correlation between serum ALP and the circulating number of CD34- positive cells. Second, because of the limited number of participants, we could not perform a drinking status-specific analysis even though serum ALP is known to be associated with drinking status [5, 30]. However, a significant correlation between serum ALP and circulating CD34-positive cells was observed even after adjustment for alcohol consumption. Furthermore, the significant correlation between serum ALP and alcohol consumption was observed only among participants with high BMI.

Although the correlation between serum ALP levels and circulating CD34-positive cells was shown to be independent of the traditional risk factors, we did not adjust for other potential confounding factors whose values were associated with serum ALP, such as caloric, protein, vitamin $\mathrm{C}$, magnesium, and zinc deficiencies [31].

In conclusion, we showed that serum ALP correlates positively with circulating CD34-positive cells among a general population of elderly Japanese men, especially those with low BMI $\left(<23 \mathrm{~kg} / \mathrm{m}^{2}\right)$. These findings suggest that serum ALP levels may constitute an efficient tool for estimating the risk of insufficient vascular homeostasis, especially for participants with comparatively few classical cardiovascular risk factors. 


\section{Abbreviations}

ALP: alkaline phosphatase; ALT: serum alanine aminotransferase: AST: aspartate aminotransferase; BMI: body mass index; Ca: calcium; CAVI: cardio-ankle vascular index; Cl: confidence intervals; CIRCS: Circulatory Risk in Communities Study; GFR: glomerular filtration rate; HbA1c: hemoglobin A1c; HDL: HDL-cholesterol; JSCC: Japanese Society of Clinical Chemistry; P: phosphorus; TG: triglyceride; WHO: World Health Organization; $\beta$ : parameter estimates; $\gamma$-GTP: $\gamma$-glutamyltranspeptidase.

\section{Competing interests}

All authors have read and approved submission of the manuscript, and that material in the manuscript has not been published and is not being considered for publication elsewhere in whole or in part in any language except as an abstract. The person in acknowledgement has been seen and approved mentions of his name in the article.

\section{Authors' contributions}

YS carried out the design of the study, performed the statistical analysis, interpreted the data, and drafted or revised the manuscript. SS, JK, HY, MN, $\mathrm{KT}, \mathrm{NH}, \mathrm{NA}$, and KK designed the study, were involved in data collection, and checked the manuscript. HY and NT participated in the study concept and checked the manuscript. TM was a general coordinator and designed the study. All authors read and approved the final manuscript.

\section{Acknowledgements}

This study was supported by Grants-in-Aids for Scientific Research from the Japan Society for the Promotion of Science (No. 25291107 and No. 15K07243). We are grateful to the staff of Goto city office for their outstanding support. All authors have read and approved submission of the manuscript and that material in the manuscript has not been published and is not being considered for publication elsewhere in whole or in part in any language except as an abstract. The persons mentioned in this section have seen and approved the mention of their names in this article.

\section{Author details}

'Department of Community Medicine, Nagasaki University Graduate School of Biomedical Sciences, Nagasaki, Japan. ${ }^{2}$ Department of Island and Community Medicine, Nagasaki University Graduate School of Biomedica Sciences, Nagasaki, Japan. ${ }^{3}$ Department of Laboratory Medicine, Nagasak University Hospital, Nagasaki, Japan. ${ }^{4}$ Division of Strategic Collaborative Research Center for Promotion of Collaborative Research on Radiation and Environment Health Effects, Nagasaki University Graduate School of Biomedical Sciences, Nagasaki, Japan. ${ }^{5}$ Department of Endocrinology and Metabolism, Unit of Translational Medicine, Nagasaki University Graduate School of Biomedical Sciences, Nagasaki, Japan. ${ }^{6}$ Center for Health and Community Medicine, Nagasaki University, Nagasaki, Japan. ${ }^{7}$ Department of Global Health, Medicine and welfare, Atomic bomb Disease Institute, Nagasaki University Graduate School of Biomedical Sciences, Nagasaki, Japan.

\section{Received: 4 April 2015 Accepted: 10 January 2016}

\section{Published online: 14 January 2016}

\section{References}

1. Cheung BM, Ong KL, Wong LY. Elevated serum alkaline phosphatase and peripheral arterial disease in the United States National Health and Nutrition Examination Survey 1999-2004. Int J Cardiol. 2009;135:156-61.

2. Tonelli M, Curhan G, Pfeffer M, Sacks F, Thadhani R, Melamed ML, et al. Relationship between alkaline phosphatase, serum phosphate, and all-cause or cardiovascular mortality. Circulation. 2009;120:1784-92.

3. Ryu WS, Lee SH, Kim CK, Kim BJ, Yoon BW. Increased serum alkaline phosphatase as a predictor of long-term mortality after stroke. Neurology. 2010;75:1995-2002.

4. Abramowitz M, Muntner P, Coco M, Southern W, Lotwin I, Hostetter TH, et al. Serum alkaline phosphatase and phosphate and risk of mortality and hospitalization. Clin J Am Soc Nephrol. 2010:5:1064-71.

5. Shimizu Y, Imano H, Ohira T, Kitamura A, Kiyama M, Okada T, et al. Alkaline phosphatase and risk of stroke among Japanese: the Circulatory Risk in Communities Study (CIRCS). J Stroke Cerebrovasc Dis. 2013;22:1046-55.

6. Shioi A, Katagi M, Okuno Y, Mori K, Jono S, Koyama H, et al. Induction of bone-type alkaline phosphatase in human vascular smooth muscle cells: roles of tumor necrosis factor-alpha and oncostatin $\mathrm{M}$ derived from macrophages. Circ Res. 2002;91:9-16.

7. Takakura N, Watanabe T, Suenobu S, Yamada Y, Noda T, Ito Y, et al. A role for hematopoietic stem cells in promoting angiogenesis. Cell. 2000;102:199-209.

8. Yamada Y, Takakura N. Physiological pathway of differentiation of hematopoietic stem cell population into mural cells. J Exp Med. 2006;203: 1055-65.

9. Shi Q, Rafii S, Wu HM, Wijelath ES, Yu C, Ishida A, et al. Evidence for circulating bone marrow-derived endothelial cells. Blood. 1998;92:362-7.

10. Calvi LM, Adams GB, Weibrecht KW, Weber JM, Olson DP, Knight MC, et al. Osteoblastic cells regulate the haematopoietic stem cell niche. Nature. 2003; 425:841-6.

11. Zhang J, Niu C, Ye L, Huang H, He X, Tong WG, et al. Identification of the haematopoietic stem cell niche and control of the niche size. Nature. 2003; 425:836-41.

12. Hagar S, Lampert FM, Orimo H, Stark GB, Finkenzeller G. Up-regulation of alkaline phosphatase expression in human primary osteoblasts by concultivation with primary endothelial cells is mediated by p38 mitogenactivated protein kinase-dependent mRNA stabilization. Tissue Eng Part A. 2009;15:3437-47.

13. Sata M, Saiura A, Kunisato A, Tojo A, Okada S, Tokuhisa T, et al. Hematopoietic stem cells differentiate into vascular cells that participate in the pathogenesis of atherosclerosis. Nat Med. 2002:8:403-9.

14. Schoppet M, Shanahan CM. Role for alkaline phosphatase as an inducer of vascular calcification in renal failure? Kidney Int. 2008;73:989-91.

15. Lumachi F, Ermani M, Camozzi V, Tombolan V, Luisetto G. Changes of bone formation markers osteocalcin and bone-specific alkaline phosphatase in postmenopausal women with osteoporosis. Ann NY Acad Sci. 2009;1 173:60-3.

16. Taguchi A, Matsuyama T, Moriwaki H, Hayashi T, Hayashida K, Nagatsuka K, et al. Circulating CD34-positive cells provide an index of cerebrovascular function. Circulation. 2004;109:2972-5.

17. OECD (2014), OECD obesity update 2014. Available at: http://www.oecd.org/ health/obesity-update.htmAccessed 21 December 2015.

18. Ueshima H, Sekikawa A, Miura K, Turin TC, Takashima N, Kita Y, et al. Cardiovascular disease and risk factors in Asia: a selected review. Circulation. 2008:118:2702-9.

19. Atalay S, Elci A, Kayadibi H, Onder CB, Aka N. Diagnostic utility of osteocalcin, undercarboxylated osteocalcin, and alkaline phosphatase for osteoporosis in premenopausal and postmenopausal women. Ann Lab Med. 2012;32:23-30.

20. Sutherland DR, Anderson L, Keeney M, Nayar R, Chin-Yee I. The ISHAGE guidelines for CD34+ cell determination by flow cytometry. International Society of Hematotherapy and Graft Engineering. J Hematother. 1996;5:213-26.

21. Barnett D, Janossy G, Lubenko A, Matutes E, Newland A, Reilly JT. Guideline for the flow cytometric enumeration of CD34+ haematopoietic stem cells. Prepared by the CD34+ haematopoietic stem cell working party. General Haematology Task Force of the British Committee for Standards in Haematology. Clin Lab Haematol. 1999;21:301-8.

22. Imai E, Horio M, Watanabe T, Iseki K, Yamagata K, Hara S, et al. Prevalence of chronic kidney disease in the Japanese general population. Clin Exp Nephrol. 2009;13:621-30.

23. Schmidt-Lucke, Rössig L, Fichtlschere $\mathrm{S}$, Vasa M, Britten M, Kämper U, et al. Reduced number of circulating endothelial progenitor cells predicts future cardiovascular events: proof of concept for the clinical importance of endogenous vascular repair. Circulation. 2005;111:2981-7.

24. Walter DH, Ritting K, Bahlmann FH, Kirchmair R, Silver M, Murayama T, et al. Statin therapy accelerates reendothelialization: a novel effect involving mobilization and incorporation of bone marrow-derived endothelial progenitor cells. Circulation. 2002;105:3017-24.

25. Majka M, Janowska-Wieczorek A, Ratajczak J, Ehrenman K, Pietrzkowski Z, Kowalska MA, et al. Numerous growth factors, cytokines, and chemokines are secreted by human CD34(+) cells, myeloblasts, erythroblasts, and megakaryoblasts and regulate normal hematopoiesis in an autocrine/ paracrine manner. Blood. 2001;97:3075-85.

26. Brusnahan SK, McGuire TR, Jackson JD, Lane JT, Garvin KL, O'Kane BJ, et al. Human blood and marrow side population stem cell and Stro-1 positive bone marrow stromal cell numbers decline with age, with an increase in quality of surviving stem cells: correlation with cytokines. Mech Ageing Dev. 2010:131:718-22

27. Garvin K, Feschuk C, Sharp JG, Berger A. Does the number or quality of pluripotent bone marrow stem cells decrease with age? Clin Orthop Relat Res. 2007:465:202-7. 
28. WHO Expert Consultation. Appropriate body-mass index for Asian populations and its implications for policy and intervention strategies. Lancet. 2004;363:157-63.

29. Wilkinson JH. Clinical applications of isoenzymes. Clin Chem. 1970;16:733-9.

30. Shimizu Y, Nakazato M, Sekita T, Kadota K, Yamasaki H, Takamura N, et al. Association between alkaline phosphatase and hypertension in a rural Japanese population: the Nagasaki Islands study. J Physiol Anthropol. 2013;32:10.

31. Lum G. Significance of low serum alkaline phosphatase activity in a predominantly adult male population. Clin Chem. 1995;41:515-8.

Submit your next manuscript to BioMed Central and we will help you at every step:

- We accept pre-submission inquiries

- Our selector tool helps you to find the most relevant journal

- We provide round the clock customer support

- Convenient online submission

- Thorough peer review

- Inclusion in PubMed and all major indexing services

- Maximum visibility for your research

Submit your manuscript at www.biomedcentral.com/submit
Biomed Central 